\title{
ECONOMIC GROWTH AND BETA-CONVERGENCE BETWEEN EU AND UKRAINE
}

\author{
Andrii VERSTIAK \\ Chernivtsi National University \\ E-mail: a.verstyak@chnu.edu.ua \\ Oksana VERSTIAK \\ Institute of Trade and Economics \\ E-mail: oks1982@gmail.com \\ Svyatoslav ISHCHENKO \\ Chernivtsi National University \\ E-mail: isv.emm@gmail.com \\ Serhii ZIUKOV \\ Chernivtsi National University \\ E-mail: s.zyukov@chnu.edu.ua \\ doi:10.13165/IE-14-8-1-09
}

\begin{abstract}
The empiric analysis of convergence processes between Ukraine and EU countries showed that the most spreading method of convergence presence in the rate of economic development is the reduction of the inequality of GDP per capita level among the countries groups. The main characteristics of the convergence hypothesis are checked on the example of EU and Ukraine. Thus, the economic dependence of emerging countries from developed countries is primarily manifested in the fact that developed countries are net-exporters of capital to developing countries, while developing countries are, in fact, their debtors. The hypothesis of EU and Ukraine integration is checked on the base of convergence test.
\end{abstract}

JEL classification: F15, O47

Keywords: global crisis, economic convergence, $\beta$-convergence, $\sigma$-convergence, divergence, international integration, foreign (external) trade, integration processes, Ukraine.

Reikšminiai žodžiai: globali krizė, konvergencija, divergencija, ekonominė konvergencija, tarptautinè integracija, užsienio prekyba, integracijos procesai Ukrainoje.

\section{Introduction}

The history of European integration shows that due to a set of objective reasons, integration process was among the countries that have achieved relatively high levels of 
economic and political development. The basis of integration except the natural process of increasing interdependence of national economies is a need for mutual adjustment and joint regulation of economic processes across the entire economic complex. The effectiveness of this regulation depends on the level of national economic, social and legal systems.

From the start, the entire EU mechanism was created to help less developed countries and regions to achieve more advanced level, i.e. to ensure economic convergence. Creating the conditions for economic convergence is crucial for an integrated association existence.

In theory of economic growth there is assumed that the initial differentiation of the development level is the result of exogenous shocks and imperfect adjustment mechanism. In accordance with the hypothesis of convergence, if the country's economy at the initial time is further away from the position of stable equilibrium, its growth rate will be higher than in the economy, which is closer to equilibrium. So, in the long term differentiation disappears. The most common hypothesis of convergence is used to study the dynamics and differences in the level of GDP.

\section{The concepts of economic convergence}

It should be noted that in the economic literature there is no single definition of "convergence" and it is only mentioned several concepts of convergence hypothesis. There are two most widely used concepts of convergence - so-called beta and sigma convergence concepts (Barro, Sala-i-Martin, 1991, 1992, 1995, 2004; Solow, 1957; Bernard, 1996; Henin and Le Pen, 1995).

Concept of $\beta$-convergence defines convergence as a process of "building" in which countries with lower levels of development have higher rates of economic growth. The second type of convergence, i.e. $\sigma$-convergence is defined as a reduction in the time variance of the GDP per capita distribution or another income indicator.

Hypotheses of $\beta$-convergence and $\sigma$-convergence are interdependent, but not equivalent. In several papers (Barro, Sala-i-Martin, 1991, 1992, 1995, 2004) it was shown that with absolute $\beta$-convergence $\sigma$-convergence does not directly follow. (Henin and Le Pen, 1995) proposed the relationship interpretation between absolute $\beta$-convergence and $\sigma$-convergence. Absolute $\beta$-convergence indicates the existence of the trend towards reducing the gap in GDP per capita. At the same time, random shocks affects the economy of countries (regions) may counteract this trend and temporarily increase the distribution variance of the GDP per capita.

The starting point for the convergence analysis is the so-called unconditional model of $\beta$-convergence, which is based on the neoclassical theory of growth (Solow, 1956, 1957). Within this model, the economic growth is positively correlated with the gap at the initial time between initial per capita income for the country (region) and income per capita in steady state equilibrium, which is the same for all regions. In steady state equilibrium countries are on a stable growth path, characterised by constant growth rate of per capita income. In accordance with the model, countries with lower development level should grow at a faster rate than those with higher levels of development, so in the long term regional levels of economic development should be aligning. 
Formally unconditional convergence model can be written as (Barro, Sala-i-Martin, 1992)

$$
g_{T}=\alpha+\beta y_{0}+\varepsilon, \varepsilon \sim N\left(0, \sigma^{2} I\right)
$$

where $g_{T}$ - logarithm of the average growth rate for the period $\mathrm{T} ; y_{0}$ - logarithm of the variable at initial level that is tested for convergence; $\alpha$-parameter that contains the norm of technological progress and the level of per capita income in the steady state equilibrium; $\beta$ - rate of convergence; $\varepsilon$ - random component.

The process of convergence is usually characterised by the speed of convergence and time to overcome the half of distance that separates the economy of the country (region) from its steady state. These coefficients can be calculated by evaluating the coefficient of convergence $\beta$ as $\hat{b}=-\ln (1-T \hat{\beta}) / T$ and $h l=\ln (2) / \hat{b}$. Rate of convergence is determined by the sign and value of the coefficient $\beta$. If $\beta<0$, then the convergence is observed, if $\beta>0$, then the divergence is observed.

The hypothesis of a negative correlation between average growth rate and the initial income per capita is verified in the model of unconditional convergence in line with neoclassical growth theory (Barro, Sala-i-Martin, 2004). At the same time, the theory assumes that countries (regions) tend to a single trajectory of proportional growth.

Countries (regions) studying in this model have rather uniform economic structure and are characterised only by time disparities in economic development, which are explained by differences in initial levels of per capita income. It is logical to assume that different countries (regions) have different trajectories of proportional growth and, consequently, different long-term growth rates. In this case, the alignment of economic development of countries (regions) cannot exist. The objective of regional policy in this case is the adoption of such tools that can raise the growth level of underdeveloped areas.

The assumption that the countries (regions) have different stable path of growth is formalised within the model of conditional $\beta$-Convergence as follows (Barro, Sala-iMartin, 1992):

$$
g_{T}=\alpha+\beta y_{0}+Z \phi+\varepsilon, \varepsilon \sim N\left(0, \sigma^{2} I\right)
$$

where $Z$ is matrix of regional growth factors that characterise the equilibrium.

Thus, the model of conditional convergence hypothesis is tested for the presence of negative correlation between average growth rate and initial per capita income in the presence of regulatory factors that characterise regional differences in the levels of stable equilibrium states.

In order to analyse the relationship between the two types of convergence, consider the basic equation of the neoclassical growth model that links the growth rate of per capita income $\left(y_{i}\right)$ for a certain period of time from the initial level of income (Barro, Sala-i-Martin, 2004):

$$
\ln \left(\frac{y_{i, t}}{y_{i, t-1}}\right)=a_{i t}-\left(1-e^{-\beta}\right) \ln \left(y_{i, t-1}\right)+u_{i, t} .
$$


Neoclassical growth theory shows that a free member $a_{i t}$ is the sum of a variable that reflects the technological process, and the value factor which is the logarithm of the equilibrium value of income in the country. This is the essence of the conditional convergence concept, since income is taken into account that corresponds to a stable equilibrium position.

Considering the countries (regions), it is assumed that free member $a_{i t}$ is the same for all regions. Moreover, if $\beta>0$, then from equation (3) it follows that countries with lower levels of development are characterised by higher rates of economic development. Assuming that the random deviation $u_{i, t}$ has a distribution with parameters $\left(0, \sigma_{u, t}^{2}\right)$ and is distributed independent of $\log \left(y_{i, t-1}\right)$ and $u_{j, t}, i \neq j$, we can obtain an expression that allows following the connection between $\beta$ and $\sigma$-convergence:

$$
\sigma_{t}^{2}=\frac{\sigma_{u}^{2}}{1-e^{-2 \beta}}+\left(\sigma_{0}^{2}-\frac{\sigma_{u}^{2}}{1-e^{-2 \beta}}\right) e^{-2 \beta t},
$$

where $\sigma_{0}^{2}$ - variance $\ln \left(y_{i, 0}\right)$. It follows that $\sigma_{t}^{2}$ tends to its equilibrium state $\sigma_{u}^{2} / 1-e^{-2 \beta}$, which increases with the $\sigma_{u}^{2}$ but decreases with the increase of $\beta$. Thus, the positive coefficient $\beta$ does not mean reducing $\sigma_{t}^{2}$ i.e. the presence of convergence. However, $\beta$-convergence is a necessary but insufficient condition for the existence of $\sigma$-convergence. Thus, the $\sigma$-convergence is observed in such cases where $\beta$-convergence reduces the effect of random shocks. Lichtenberg distributed this conclusion on the conditional $\beta$-convergence (Lichtenberg, 1994).

\section{Economic convergence: empirical evidence in between the EU and Ukraine}

Current issue raised in foreign literature is to test the hypothesis of the convergence presence/absence. In particular, Lichtenberg offers test convergence hypothesis, which says that variation of performance between countries decreases over time (Lichtenberg, 1994). If $y_{i t}=\ln \left(Y_{i t}\right)$ (Where $Y_{i t}$ a performance of the country $i$ and $\sigma_{t}^{2}=\sum\left(y_{i t}-\bar{y}\right)^{2} / N$ - variation $y_{i t}$ between countries in time $\left.t\right)$, then Lichtenberg argues ${ }^{i}$ that $\sigma_{1}^{2} / \sigma_{T}^{2}$ has $F(N-2, N-2)$-distribution in the case when performance between countries is not moving closer in time, where $N$ is the number of countries and $T$ is the last year of the sample. Thus:

$$
T_{1}=\frac{\sigma_{1}^{2}}{\sigma_{T}^{2}},
$$

(Carey and Klomp, 1997) conducted a critical analysis of the Lichtenberg convergence hypothesis (Lichtenberg, 1994). After a model experiment scientists argue that test of Lichtenberg hypotheses leads to a small probability of the hypothesis of convergence. Instead, Carey and Klomp offer two alternative tests to verify presence/absence of the convergence hypothesis. The authors receive the first statistical test $T_{2}$ using the 
likelihood ratio test statistic and the second $T_{3}$ adjusting the statistical test Lichtenberg $T_{4}$ (Lichtenberg, 1994). These tests are formalised as follows (Carey and Klomp, 1997):

$$
\begin{aligned}
& T_{2}=(N-2,5) \ln \left(1+0,25 \frac{\left(\sigma_{0}^{2}-\sigma_{T}^{2}\right)^{2}}{\sigma_{0}^{2} \sigma_{T}^{2}-\sigma_{0 T}^{2}}\right) \stackrel{d}{\longrightarrow} \chi^{2}(1), \\
& T_{3}=\frac{\sqrt{N}\left(\sigma_{1}^{2} / \sigma_{T}^{2}-1\right)}{2 \sqrt{1-\pi^{2}}} \stackrel{d}{\longrightarrow} N(0,1),
\end{aligned}
$$

where $T_{3}$ has a normal distribution with $N-1$ degrees of freedom, $N$ - number of countries $\sigma_{0 T}$ - covariance of productivity in the first and last periods, $\pi$ - parameter of regression $y_{i t}=\pi y_{i 1}+u_{i}$, a statistical test $T_{2}$ has $\chi^{2}(1)$-distribution.

Carey and Klomp analysed hypotheses using the data on GDP per capita for 22 countries in OECD. All of the three statistical tests showed reduction in performance of variation. However, when the authors used tests for the period from 1960 to 1985, the statistic test of Lichtenberg $T_{1}$ showed a lack of convergence in terms of GDP per capita, while the other two tests $T_{2}$ and $T_{3}$ fixed convergence. The authors also analysed the convergence for short periods of time during 1950-1994 divided into 12 sub-periods. It received a low hypothesis probability of the existence of convergence under Lichtenberg test, which confirmed its low efficiency.

We have got GDP per capita level for EU-27 and Ukraine for the period 2004-2012. Distribution of GDP per capita (current US\$) is shown in Fig. 1. Separate calculations were made for the crisis point of 2008.

The concept of $\sigma$-convergence is valid in the case when a decrease in the dispersion index of GDP per capita for the group of countries is observed. That is, if $\sigma_{t+T}<\sigma_{t}$, where $\sigma_{t}$ is a measure of dispersion, then $\sigma$-convergence is observed. To prove this concept, the most commonly used indicators are indicators of variance, standard deviation or coefficient of variation. As part of this work, $\sigma$-convergence was calculated based on the coefficient of variation, weighted coefficient of variation (taking into account the proportion of the country's population to the total) and the Theil index. Values of $\sigma$-convergence characteristics, which are calculated for GDP per capita for 2004-2012, proved the existence of rapprochement between Ukraine and the EU. It was found that the level of inequality indicated by the value of GDP per capita is not increasing, but decreasing. This analysis of various inequality indicators yielded similar results. It should be noted that for the intervals of 2004-2008 and 2008-2012, the presence of $\sigma$-divergence was observed. During almost the entire study period (2004-2012) Theil index was close to zero (the lowest value of 0.0435 was recorded in 2004), i.e. a reduction of disparities between the EU Member States and Ukraine in terms of GDP per capita was observed. The increase in this inequality was observed only in the intervals of 2004-2008 and 2004-2012. 
Figure. 1. GDP per capita (current US\$), EU27+Ukraine

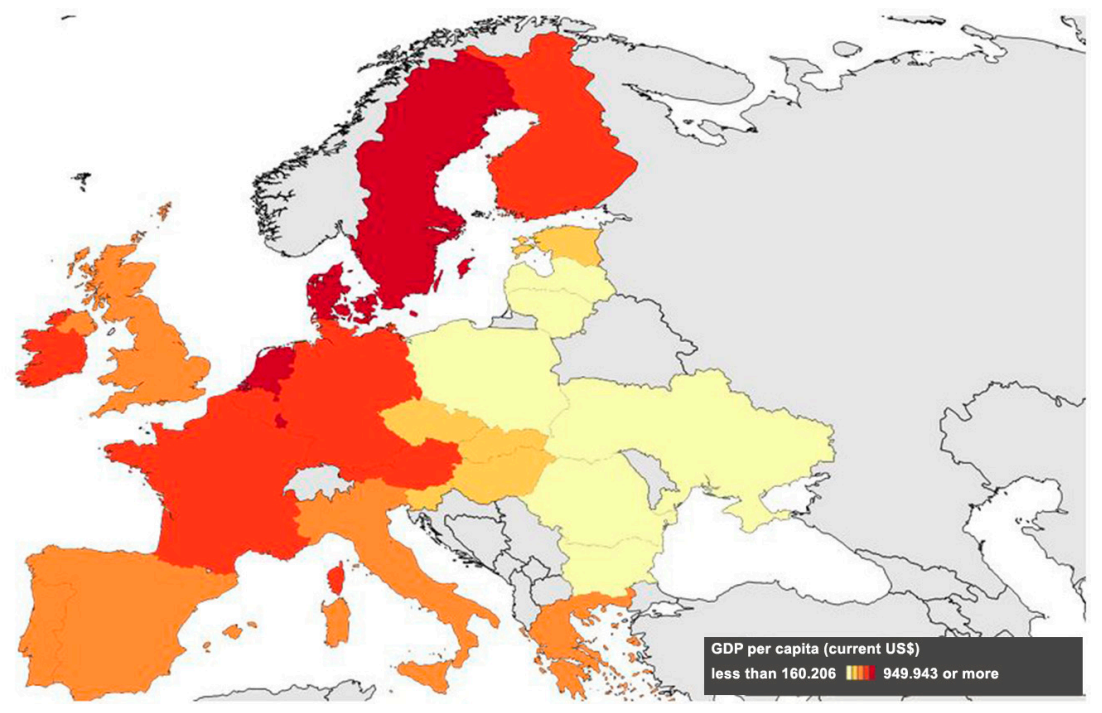

Source: The World Bank (2013)

After receiving the data about the availability of $\sigma$-convergence between Member States of the EU and Ukraine, we should conduct an analysis of statistical tests of Lichtenberg $\left(T_{1}\right)$, Carey and Klomp $\left(T_{2}, T_{3}\right)$ according to (5-7).

To check convergence availability, we need to verify two hypotheses:

1. $H_{0}$ - no convergence hypothesis states that the variance of GDP per capita in the period $\mathrm{T}$ is equal to the variance of that indicator in period $0, H_{0}: \sigma_{T}^{2}=\sigma_{0}^{2}$;

2. $H_{1}$ - hypothesis of convergence, $H_{1}: \sigma_{T}^{2}<\sigma_{0}^{2}$.

Test results of the above hypotheses are shown in Table 1. According to the results of testing the hypothesis of presence/absence of $\sigma$-convergence of GDP per capita between the EU Member States and Ukraine, we can draw the following conclusions:

1) according to the test $T_{1}$ we accepted the hypothesis $H_{0}: \sigma_{T}^{2}=\sigma_{0}^{2}$ the lack of convergence as false $\sigma_{T}^{2}>\sigma_{0}^{2}$;

2) based on $T_{2}$ test results the hypothesis of no convergence $H_{0}: \sigma_{T}^{2}=\sigma_{0}^{2}$ was rejected and the hypothesis $H_{1}: \sigma_{T}^{2}<\sigma_{0}^{2}$. was accepted, which confirms earlier findings;

3) the results of $T_{3}$ test also indicate rejection of the hypothesis $H_{0}$. Thus, we accepted the hypothesis $H_{1}: \sigma_{T}^{2}<\sigma_{0}^{2}$. the presence of convergence. 
Table 1. Empirical test results of statistical tests of convergence

\begin{tabular}{|c|c|c|c|c|}
\hline $\begin{array}{c}\text { Statistical } \\
\text { test }\end{array}$ & $\begin{array}{c}\text { Received } \\
\text { value }\end{array}$ & $\begin{array}{c}\text { Critical } \\
\text { value }\end{array}$ & Distribution & Conclusion \\
\hline$T_{1}$ & 0.2501 & 1.9292 & $F_{95 \%}(N-2, N-2)$ & $T_{1}^{*}>T_{\kappa \rho}:$ No convergence \\
\hline$T_{2}$ & 25.8080 & 3.8415 & $\chi_{95 \%}^{2}(1)$ & $T_{1}^{*}>T_{\kappa \rho}:$ The existing convergence \\
\hline$T_{3}$ & 1.3013 & 1.2816 & $N_{90 \%}(0,1)$ & $T_{1}^{*}>T_{\kappa \rho}:$ The existing convergence \\
\hline
\end{tabular}

Source: Author's calculations

These results prove a critical analysis of Carey and Klomp on inadequacy of the Lichtenberg $T_{1}$ test. The confirmation of tests $T_{2}$ and $T_{3}$ leads to the general conclusion that $\sigma$-convergence of GDP per capita exists between the EU Member States and Ukraine.

Summarising the results, we can state that the concept of $\sigma$-convergence was confirmed by the data on the EU and Ukraine. It was found that the level of inequality indicated by the value of GDP per capita is not increasing, but decreasing. This analysis of various indicators of inequality yielded similar results.

Availability of $\beta$-convergence reflects a negative statistical correlation between the growth rate of income per capita and its initial level during the cross-sectional analysis of countries. This data regression model determines the kind $\beta$-convergence that should be checked. In case of estimated regression steam dependence of the income growth rate on a constant and the initial level of this index, we verify the existence of absolute convergence. If the equation includes additional exogenous parameters that characterise the differences in the level of production technology, the savings rate, population growth and other parameters, we test the hypothesis of conditional convergence.

Let us analyse the results of paired regression of the growth rate of GDP per capita in 2012, relative to 2004 for equation (under 1):

$$
\left(\frac{1}{T}\right)\left(\ln y_{i T}-\ln y_{i 0}\right)=a+b \ln \left(y_{i, 0}\right)+\varepsilon_{i}
$$

where $y_{i 0}$ and $y_{i T}$ - GDP per capita in the initial and final periods, $b=\frac{1-e^{-\beta T}}{T}-$ rate of convergence (shows how the value of economic growth will decrease in percentage terms by increasing the initial per capita GDP by $1 \%) \beta=-\ln (1-T b) / T$ - rate of convergence (shows how the gap is shrinking every year), $T$ - length of time interval, $a$ - constant, $\varepsilon_{i}$ - random error, $i=\overline{1, n}$.

According to (8), on the basis of calculations, pair regression equation is:

$$
\left(\frac{1}{T}\right)\left(\ln y_{i T}-\ln y_{i 0}\right)=0,163-0,0126 \ln \left(y_{i, 0}\right) \text {, }
$$

i.e. the rate of convergence $b=-0,0126$. Speed of convergence $\beta$ is 0.0049 . The annual gap will be $0.49 \%$ per year, which is a relatively low rate in these calculations (in works of Barrow and Sala-i-Martin, the rate of convergence constituted 2 to $3 \%$ per year). In 
other words, poorer countries in 2004 grew at a rate that was $0.49 \%$ and was higher than the growth rate of countries with GDP per capita in 2004. Based on that $b<0$ and $\beta<0$ we can conclude that the entire study period confirmed the concept of absolute $\beta$-convergence for the $\mathrm{EU}$ members and Ukraine.

A more accurate conclusion can be drawn by conducting an econometric analysis of convergence rate. The correlation coefficient $r=-0,5291$, connection between these factors is moderate and back. The index of correlation (empirical correlation ratio) is $\eta=0,5833$. The resulting value indicates that GDP per capita in 2004 had moderate impact on growth rate of GDP per capita in 2012.

Coefficient of determination $R^{2}=0,2795$, i.e. $27.9489 \%$ of change in GDP per capita in 2004 lead to changes of the growth rate of GDP per capita in 2012. The accuracy of regression selection was low. Checking of hypotheses on the coefficients of the linear regression equation allowed obtaining $t_{b}=4,39$, statistically significant regression coefficient $b$ was confirmed. $F=10,111, F c r=4.23$. Because $F>F c r$, the coefficient of determination is statistically significant.

The results of evaluations confirm the existence of absolute $\beta$-convergence for the EU members and Ukraine for the period 2004-2012 and 2004-2008 with 95\% confidence level.

Figure 2 shows the dispersion of the logarithm values of average growth for the period from 2004 to 2008 (and 2012), depending on the logarithm of per capita in 2004.

The chart clearly shows one separate result - Ukraine (before and after the crisis period). Indeed Ukraine has had the lowest growth rate (log) GDP per capita in 20042012. Calculations for the data excluding Ukraine (only the 27 EU Member States) gave the following results. Rate of convergence $b=-0,0173$. Speed of convergence $\beta$ is 0.0065 . This means that the annual gap will be $0.65 \%$ per year, which is also a relatively low rate in such calculations. In other words, the poorer countries in 2004 grew at a rate of $0.74 \%$ that was higher than the growth rate of countries with GDP per capita in 2004. Based on that, $b<0$ and $\beta<0$, we can conclude that the entire study period confirmed the concept of absolute $\beta$-convergence for the EU Member States.

The correlation coefficient $r=-0,7858$, relationship between these factors is strong and opposite. The index of correlation (empirical correlation ratio) is $\eta=0,7211$. The resulting value indicates that GDP per capita in 2004 significantly affected growth rate of GDP per capita in 2012.

Coefficient of determination $R^{2}=0,6262 \%$ of the change GDP per capita in 2004 led to changes of the growth rate of GDP per capita in 2012. The accuracy of selection regression was high. Testing hypotheses about the coefficients of the linear regression equation allowed obtaining $t_{b}=8,15$, i.e. statistically significant regression coefficient $b$ was confirmed. $F=40,3508, F c r=4,26$. Because $F>F c r$, the coefficient of determination is statistically significant.

The results of evaluations confirm the existence of absolute $\beta$-convergence for the EU Member States for the period 2004-2012 with 95\% confidence level. The inclusion of Ukraine in the sample did not significantly affect the rate and pace of convergence, thus we can draw a general conclusion about the convergence of the EU Member States and Ukraine. 


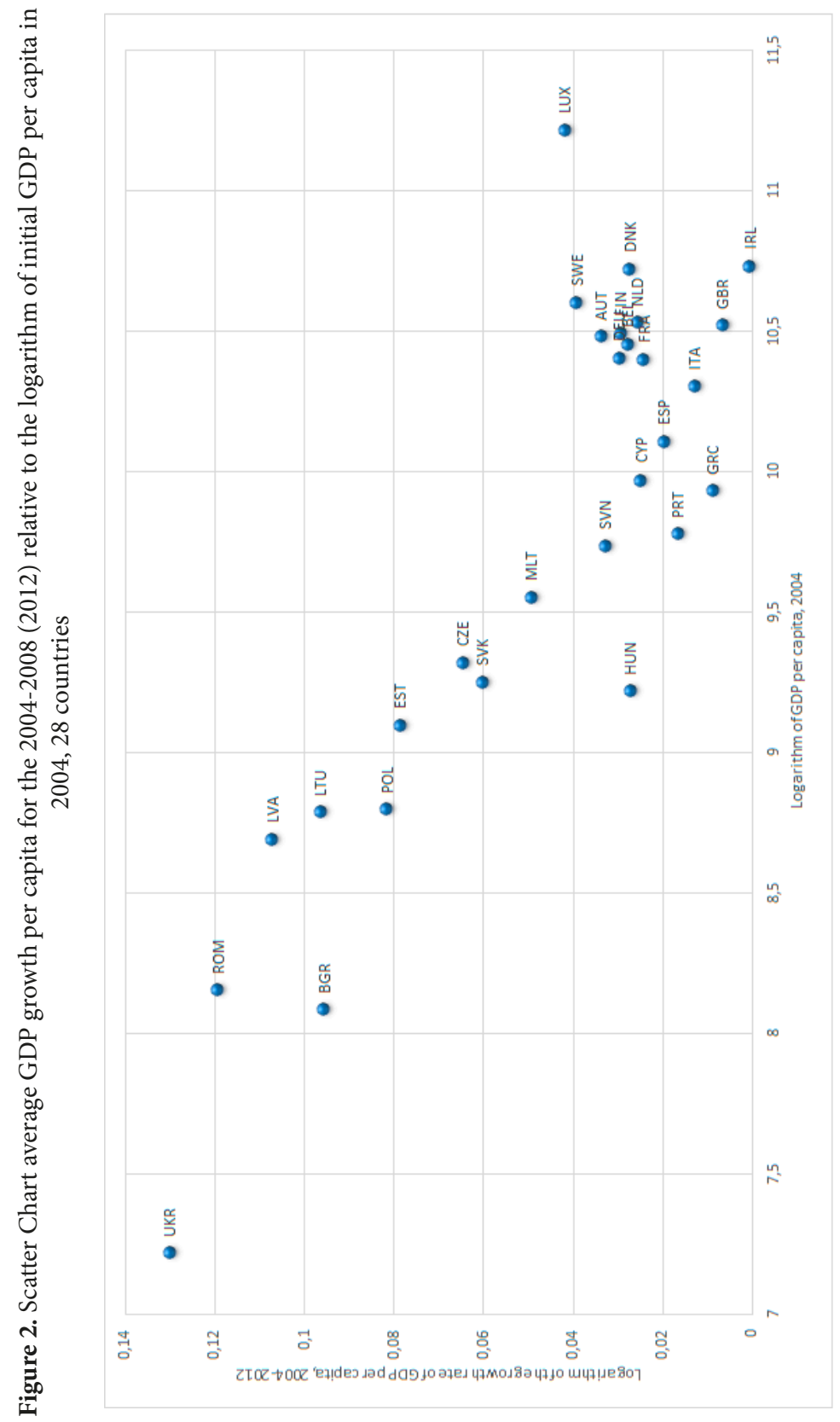




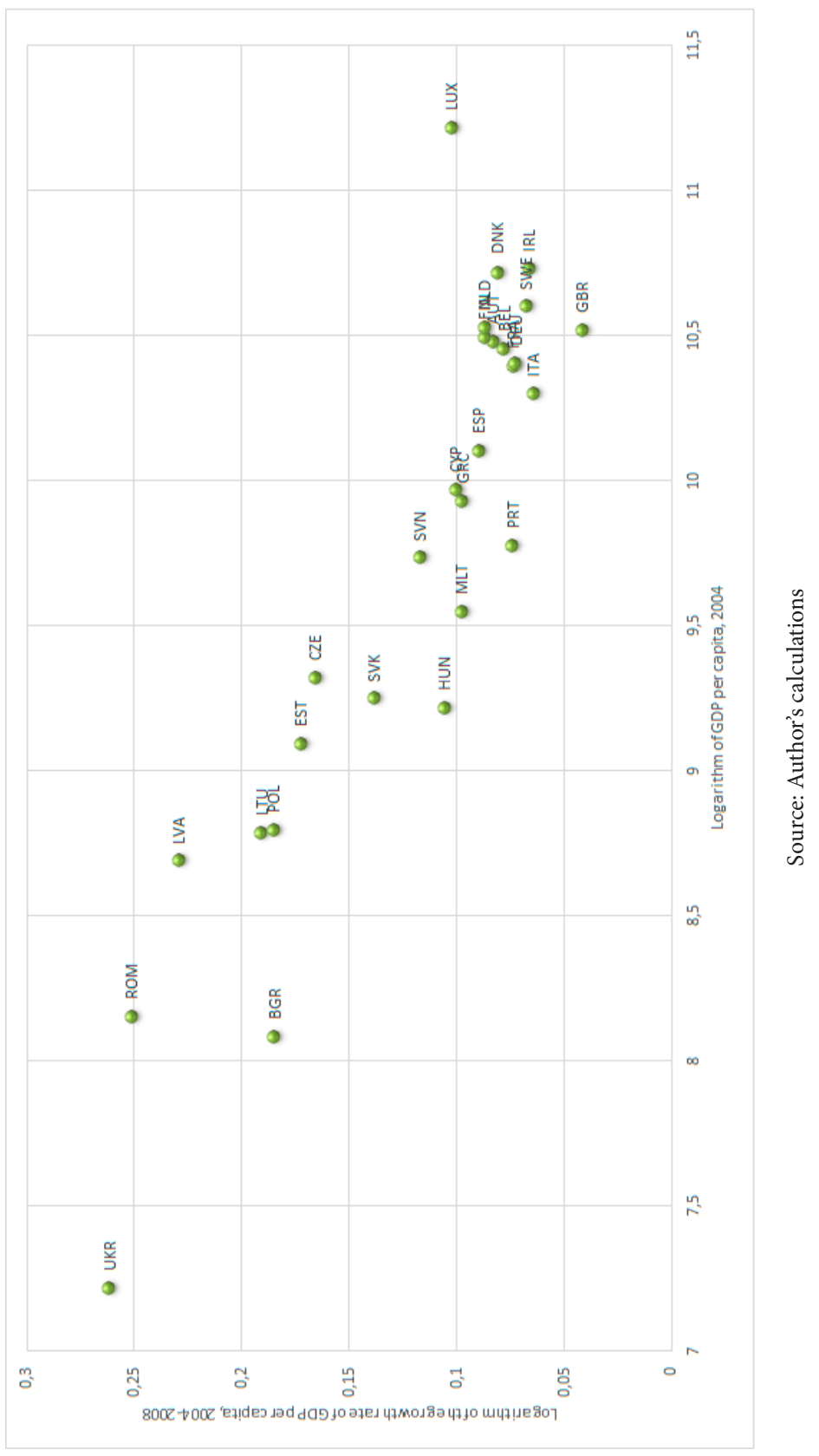




\section{Conclusion}

The study of the convergence problem showed the following results:

1. The estimation of the convergence rate for countries participating in the EU and Ukraine was made using international experience of econometric modelling. The results can be used to determine the efficiency of integration policy and to generate recommendations for its improvement.

2. The classification of convergence mechanisms was suggested, which allows determining the level of economic policy that reduces disparities between the EU Member States and Ukraine: promotion of technological progress, development of international cooperation.

3. A system of models of economic growth, and forecasts at a theoretical level on the presence/absence of convergence were suggested.

4. The calculations show that $\sigma$-convergence was confirmed by the data for the EU and Ukraine. The conclusion was reached that the level of inequality indicated by the value of GDP per capita was not increasing, but was decreasing. This analysis of various indicators of inequality yielded similar results. It should be noted that for the intervals 2004-2008 and 2008-2012, the presence of $\sigma$-divergence was observed.

5. Statistical hypothesis tests were held for presence/absence of $\sigma$-convergence of GDP per capita between the EU and Ukraine. The results confirmed the conclusions of the study of foreign scientists Lichtenberg, Cary and Klomp on statistics $T_{1}, T_{2}, T_{3}$. These tests also showed the presence of $\sigma$-convergence for the investigated variable.

\section{References}

1. Barro, R.J.; Sala-i-Martin, X. (2004) Economic Growth (Cambridge, Massachusetts; London, England, MIT Press).

2. Barro R.J; Sala-i-Martin, X. (Ed.) (1991) "Convergence across states and regions", Brookings Papers on Economic Activity, 1, 107-158.

3. Barro, R. J. and Sala-i-Martin, X. X. (1992) Convergence. Journal of Political Economy 100, 223-251.

4. Barro, R.J., Sala-i-Martin, X.X. (1995) Economic Growth. McGraw Hill, New.

5. Bernard, A. B. and Jones, C. J. (1996) Technology and Convergence, Economic Journal, 106, 1037-1004.

6. Carree, Martin \& Klomp, Luuk (1997) “Testing the convergence hypothesis" Open Access publications from Maastricht University: 27-38, Maastricht University.

7. Hénin, P.Y. and Le Pen, Y. (1995). Les episodes de la Convergence Européenne. Revue Economique 46 3, pp. 667-677.

8. Lichtenberg, Frank, R. (1994). Testing the Convergence Hypothesis. this REVIEW 76, 576-579.

9. Solow, Robert (1956). A Contribution to the Theory of Economic Growth. Quarterly Journal of Economics, 70, 65-94. 
10. Solow, Robert, M. (1957). The Technical Change and the Aggregate Production Function. Review of Economics and Statistics 39:312-320.

11. The World Bank (2013). Retrieved (07/02/1982) from http://databank.worldbank. org/data/home.aspx

\section{EKONOMIKOS AUGIMAS IR BETA KONVERGENCIJA TARP ES IR UKRAINOS}

Santrauka. Empirinis konvergencijos procesų tarp Ukrainos ir ES šaliu tyrimas parodè, kad labiausiai pastebima konvergencijos pagal BVP vienam gyventojui tarp šalių grupių. Pagrindiné konvergencijos hipotezè yra tikrinama tarp ES ir Ukrainos. Taigi, ekonominè priklausomybè nuo sparčiai augančios ekonomikos šalių iš išsivysčiusių šalių visų pirma pasireiškia tuo, kad išsivysčiusios šalys yra grynosios kapitalo eksportuotojos ị besivystančias šalis, o besivystančios šalys iš tiesų yra jų skolininkès. ES ir Ukrainos integracijos hipotezè tikrinama konvergencijos testu.

Andrii VERSTIAK - Chernivtsi National University, Ukraine.

Andrii VERSTIAK - Chernivtsi nacionalinis universitetas, Ukraina.

Oksana VERSTIAK - Institute of Trade and Economics, Ukraine.

Oksana VERSTIAK - Prekybos ir ekonomikos institutas, Ukraina.

Svyatoslav ISHCHENKO - Chernivtsi National University, Ukraine.

Svyatoslav ISHCHENKO - Chernivtsi nacionalinis universitetas, Ukraina.

Serhii ZIUKOV - Chernivtsi National University, Ukraine.

Serhii ZIUKOV - Chernivtsi nacionalinis universitetas, Ukraina. 